\title{
STUDI EVALUASI PELAKSANAAN PKL PRODI S1 PENDIDIKAN TEKNIK ELEKTRO UNIVERSITAS PENDIDIKAN GANESHA
}

\author{
I. G. N. joniartawan ${ }^{1}$, N. Santiyadnya ${ }^{2}$, G. Indrawan ${ }^{3}$ \\ 1.2Prodi Pendidikan Teknik Elektro, Universitas Pendidikan Ganesha, Singaraja \\ ${ }^{3}$ Prodi Teknik Elektronika, Universitas Pendidikan Ganesha, Singaraja \\ e-mail: joniartawan19@yahoo.co.id, santiyadnya@undiksha.ac.id, gindrawan@undiksha.ac.id
}

\begin{abstract}
Abstrak
Penelitian ini bertujuan untuk mengevaluasi efektifitas pelaksanaan Praktik Kerja Lapangan mahasiswa Prodi S1 Pendidikan Teknik Elektro. Evaluasi pelaksanaan praktik kerja lapangan meliputi perencanaan, pelaksanaan dan evaluasi praktik kerja lapangan. Penelitian ini dilakuakan di Prodi S1 Pendidikan Teknik Elektro Universitas Pendidikan Ganesha. Responden penelitian ini adalah mahasiswa Prodi S1 Pendidikan Teknik Elektro semester 8, dosen, dan perusahaan. Penelitian evaluasi merupakan penelitian kualitatif. Tahapan yang ditempuh adalah pra lapangan, lapangan, pasca lapangan. Sumber data penelitian diperoleh secara purposive sampling. Teknik pengumpulan data menggnakan metode observasi partisipan pasif, wawancara dan telaah studi dokumen. Teknik analisis data terdiri dari reduksi data, penyajian data, penarikan kesimpulan, dan verifikasi data. Pengujian keabsahan data dilakukan melalui validitas internal, validitas eksternal, uji dependability, dan uji comfirmability. Berdasarkan analisa data didapatkan hasil sebagai berikut. 1) Perencanaan pelaksanaan praktik kerja lapangan sudah sesuai dengan pedoman pelaksanaan praktik kerja lapangan, tetapi masih memiliki kekurangan; 2) pelaksanaan praktik kerja lapangan Prodi S1 Pendidikan Teknik Elektro sudah sangat efektif; 3) evaluasi pelaksanaan praktik kerja lapangan sudah mengacu pada kegiatan sehari-hari mahsiswa di lapangan dan ujian akhir praktik kerja lapangan, namun ada beberapa aspek yang belum maksimal dalam penilaian tersebut.
\end{abstract}

Kata kunci: Evaluasi, Praktik Kerja Lapangan, Efektivitas

\begin{abstract}
This study aims to evaluate the effectiveness the Field Work Practice implementation of S1 degree Electrical Engineering Education. The Evaluation of PKL includes planning, implementation and evaluation of PKL. This research was done in s1 degree of Electrical Engineering Education in Ganesha University of Education. Respondents of this research were S1 degree students of Electrical Engineering Education in eight semester, lecturer, and company. This Evaluation research was a qualitative research. The steps in this research were pre field, field, post field. Sources of research data obtained by purposive sampling. Techniques of Data collection were used passive participant observation methods, interviews and document study. Techniques of data analysis consist of data reduction, data presentation, conclusion drawing, and data verification. Validity testing of data was done through internal validity, external validity, dependability test, and comfirmability test. Based on the data analysis obtained results, among others. 1) planning the implementation of field work practices in accordance with the guidelines of the implementation of field work practices, but still have shortcomings; 2) the implementation of field work practice in S1 degree Electrical Engineering Education has been very effective; 3) Evaluation of field work practices has been referring to the daily activities of the students in the field and the final examination of field work practices, but there were some aspects that have not been maximized in the assessment.
\end{abstract}

Keywords: Evaluation, Field Work Practice, effective

\section{Pendahuluan}

Pendidikan adalah usaha sadar dan terencana untuk mewujudkan suasana belajar dan proses pembelajaran agar peserta didik secara aktif mengembangkan potensi dirinya untuk memiliki kekuatan spiritual keagamaan, pengendalian diri, kepribadian, kecerdasan, akhlak mulia, serta keterampilan yang diperlukan dirinya, masyarakat, bangsa dan Negara (UU RI No. 20 tahun 2003 Pasal 1 ayat 1). Potensi yang ada di dalam diri setiap begitu banyak dan besar. Dimana, potensi tersebut berbeda - beda pada setiap individu. Potensi yang mereka 
bawa, sudah ada sejak pertama kali mereka dilahirkan ke dunia. Potensi - potensi yang ada didalam diri mereka itu disebut juga dengan bakat. Kemudian, bakat itulah yang dapat dikembangkan dengan mendidik dan memberikan mereka pelajaran dari sejak dini. Memberikan mereka pelajaran bukanlah hal yang mudah, maka dari hal itulah diperlukan seorang pendidik.

Dengan adanya seorang pendidik kemampuan dan kepribadian atau watak mereka dapat dikembangkan supaya menjadi individu yang berguna bagi masyarakat, bangsa dan negaranya. Hal sesuai dengan tujuan pendidikan nasional yang berfungsi mengembangkan kemampuan dan membentuk watak serta peradaban bangsa yang bermartabat dalam rangka mencerdaskan kehidupan bangsa, bertujuan untuk berkembangnya potensi peserta didik agar menjadi manusia yang beriman dan bertakwa kepada Tuhan Yang Maha Esa, berakhlak mulia, sehat, berilmu, cakap, kreatif, mandiri, dan menjadi warga negara yang demokratis serta bertanggung jawab (UU RI No. 20 tahun 2003 Pasal 1 ayat 3). Berdasarkan hal tersebut, pendidikan merupakan salah satu hal terpenting dalam perkembangan seorang individu untuk dapat mengembangkan potensi yang ada didalam dirinya dengan semaksimal mungkin.

Sebagaimana yang sudah dipaparkan tadi, banyak sekali universitas-universitas dan perguruan tinggi yang terdapat di Indonesia. Khususnya di daerah Bali, saat ini Bali mempunyai banyak universitas dan perguruan tinggi yang sudah bermunculan dan terakreditasi, salah satunya, yaitu Universitas Pendidikan Ganesha. Hal ini terjadi karena lulusan dari universitas diharapkan dapat meningkatkan kualitas dan mutu pendidikan di Indonesia dengan bekerja di bidang-bidang yang fital di dunia usaha.

Sehingga dalam dunia pendidikaan saat ini yang semakin modern yang membutuhkan dan menghasilkan lulusan yang memiliki sumber daya manusia (SDM) yang bermutu, berkeahlian dan memiliki keterampilan yang baik agar bisa bersaing di dunia kerja yang makin terbuka saat ini. Pada jenjang universitas dan perguruan tinggi memiliki suatu program yang bernama Praktik Kerja Lapangan merupakan sebuah bentuk implementasi secara sistematis dan sinkron antara program pendidikan di kampus dengan penguasaan keahlian yang diperoleh melalui kegiatan kerja secara langsung di dunia kerja untuk mencapai tingkat keahlian tertentu.

Praktik Kerja Lapangan memiliki tujuan utama untuk meningkatkan keahlian dan keterampilan mahasiswa Universitas Pendidikan Ganesha terutama jurusan teknik, salah satunya, yaitu Prodi S1 Pendidikan Teknik Elektro dan lulusan yang memiliki keterampilan dan keahlian yang bagus dan bermutu yang dapat bersaing di dunia kerja yang semakin terbuka seiring dengan perkembangan dunia yang semakin maju dan terbuka. Dengan adanya program Praktik Kerja Lapangan ini diharapkan lulusan Universitas Pendidikan Ganesha, khususnya Prodi S1 Pendidikan Teknik Elektro dapat memiliki keterampilan dan keahlian yang bagus dan bermutu di bidang keahliannya masing-masing sehingga dapat bersaing di dunia usaha global yang sangat terbuka saat ini.

Program Praktik Kerja Lapangan di Prodi S1 Pendidikan Teknik Elektro Universitas Pendidikan Ganesha melakukan Praktik kerja Lapangan pada Semester VII, dimana Praktik Kerja Lapangan ini dilaksanakan selama 3 bulan untuk setiap mahasiswa, setiap mahasiswa wajib mengikuti Praktek Kerja Lapangan ini sebagai syarat mahasiswa agar bisa menyusun skripsi. Sebelum mulai melaksanakan kegiatan Praktik Kerja Lapangan, khususnya Prodi S1 Pendidikan Teknik Elektro dann mahasiswa harus menyiapkan segalanya secara matang, sehingga proses kegiatan Praktik Kerja lapangan dapat berjalan dengan lancar dan efektif. Oleh Karena Itu, Peneliti Terinspirasi Untuk Melakukan Penelitian Dengan Judul "Studi Evaluasi Pelaksanaan Praktik Kerja Lapangan (Pkl) Mahasiswa Prodi S1 Pendidikan Teknik Elektro Universitas Pendidikan Ganesha Tahun 2018".

Berdasarkan uraian latar belakang masalah yang tertuang diaas, didalam penelitian ini dibtasi bagaimana pelaksanaan praktik kerja lapangan mahasiswa Prodi S1 Pendidikan Teknik Elektro Undiksha pada tahun 2018. Bertitik tolak dari latar belakang diatas, maka perlu dirumuskan permasalahan permasalahan dalam penelitian ini adalah bagaimana perencanaan praktik kerja lapangan mahasiswa prodi S1 Pendidikan Teknik Elektro Undiksha tahun 2017?, bagaimana efektifitas pelaksanaan praktik kerja lapangan dalam hal 
meningkatkan keterampilan dan keahlian mahasiswa dalam bidang keahlian masing-masing, dan bagaimana evaluasi dari pelaksanaan praktik kerja lapangan mahasiswa prodi $\mathrm{S} 1$ Pendidikan Teknik Elektro Undiksha.

Berdasarkan rumusan masalah tersebut, tujuan penelitian ini adalah untuk mengetahui bagaimana perencanaan praktik kerja lapangan mahasiswa prodi S1 Pendidikan Teknik Elektro Undiksha, untuk mengetahui bagaimana pelaksanaan praktik kerja lapangan mahasiswa prodi S1 Pendidikan Teknik Elektro Undiksha, dan untuk mengetahui bagaimana system evalausi pelaksanaan praktik kerja lapangan mahasiswa prodi S1 Pendidikan Teknik Elektro Undiksha.

Manfaat dari penelitian ini adalah memberikan masukan pada semua pihak yang terjun langsung pada praktik kerja lapangan, seperti mahasiswa, Prodi S1 Pendidikan Teknik Elektro dan perusahaan tepat mahasiswa melakukan praktik kerja lapangan sebagai upaya pelaksanaan praktik kerja lapangan yang lebih efektif dan meningkatkan kualitas mahasiswa dan lulusa Prodi S1 Pendidikan Teknik Elektro.

Evaluasi adalah suatu prosedur ilmiah sistematis yang dilakukan untuk mengukur hasil program atau proyek (efektifitas suatu program) sesuai dengan tujuan yang direncanakan atau tidak, dengan cara mengumpulkan, menganalisis dan mengkaji pelaksaaan program yang dilakukan secara objektif. Kemudian merumuskan dan menentukan kebijakan dengan terlebih dahulu mempertimbangkan nilai-nilai positif dan keuntungan suatu program.

Michael Scriven (dalam Arikunto, 2007: 222-223) mengemukakan bahwa secara garis besar fungsi penelitian evaluasi dapat dibedakan menjadi dua, yakni fungsi formatif, untuk pengumpulan data pada kegiatan yang sedang berjalan dan digunakan untuk perbaikan, pengembangan, dan modifikasi program, dan fungsi sumatif yang dilaksanakan setelah program selesasi dilaksanakan. Penelitian evaluasi bertujuan untuk mengevaluasi komponenkomponen program dan program secara menyeluruh.

Terdapat beberapa beberapa model evaluasi sebagai strategi atau pedoman kerja pelaksanaan evaluasi program, yaitu. 1) Model CIPP merupakan singkatan (akronim) dari contect evaluation, input evaluation, process evaluation, dan product evaluation yang dikembangkan oleh Daniel Stufflebeam dan kawan-kawannya pada tahun 1968 di Ohio State University dan berorientasi pada pengambilan keputusan, 2) Model Evaluasi UCLA merupakan Evaluasi sebagai suatu proses meyakinkan keputusan, memilih informasi yang tepat, mengumpulkan dan menganalisis informasi sehingga dapat melaporkan ringkasan data yang berguna bagi pembuat keputusan dan memilih beberapa alternative, 3) Model Evaluasi Brinkerhoff, dengan mengemukakan tiga jenis desain, yaitu Dwiyogo (dalam Mestia Wendy Gustiariningsih, Ni Nyoman. 2015): a) Fixed vs Emergant evaluation design. Desain fixed ditentukan dan direncanakan secara sistematis dan desainnya dikembangkan dengan mengacu pada tujuan program. Rencana analisis dibuat sebelumnya dimana si pemakai akan menerima informasi, seperti yang telah ditentukan dalam tujuan. Strategi pengumpulan informasi dalam desain ini menggunakan tes, angket, lembar wawancara.

Pada prinsipnya desain ini terus berkembang sesuai dengan kondisi dan dapat berubah sesuai dengan kebutuhan. b) Formatif vs Summative evaluation. Evaluasi formatif digunakan untuk memperoleh data bagi keperluan revisi program, sedangkan evaluasi sumatif dibuat untuk menilai kegunaan suatu program. Pada evaluasi sumatif fokus evaluasi ditujukan pada variabel-variabel yang dipandang penting dan berkaitan dengan kebutuhan pengambilan keputusan. c) Desain eksperimental dan Quasi eksperimental vs Natural inquiry.

Desain eksperimental, quasi eksperimental dan natural inquiry desain merupakan hasil adopsi dari disiplin penelitian. Desain eksperimental dan quasi eksperimental digunakan untuk menilai suatu program yang baru diujicobakan. Sedangkan natural inquiry dilakukan dengan cara evaluator terlibat langsung dengan sumber-sumber informasi serta program yang dilaksanakannya, dan 4) Model Evaluasi Stake dikembangkan oleh Stake (1967), analisis proses evaluasi yang dikemukakannya membawa dampak yang cukup besar dalam bidang ini dan meletakkan dasar yang sederhana namun merupakan konsep yang cukup kuat untuk perkembangan yang lebih jauh dalam bidang evaluasi. Stake menekankan adanya dua dasar kegiatan dalam evaluasi ialah Descriptions dan judgement yang membedakan adanya tiga 
tahap dalam program pendidikan, yaitu: Antecedents (context), Transaction (process), Outcomes (output) (Tayibnapis. 1989: 11).

Praktik Kerja Lapangan adalah sebuah proses pengajaran dengan cara memberi kesempatan kepada mahasiswa untuk magang di tempat kerja secara nyata, baik di instansi swasta, BUMN, BUMD, ataupun instansi pemerintahan setempat. Dengan adanya PKL ini, mahasiswa bisa menerapkan ilmu yang didapat di bangku kuliah dan kampus pada kerja dunia nyata yang sesuai dengan bidangnya.

Praktik Kerja Industri bertujuan untuk memberi gambaran kepada mahasiswa pada saat bekerja, baik itu disuatu perusahaan ataupun disuatu lembaga instansi. Sedangkan secara khususnya, antara lain dapat menambah dan mengembangkan potensi ilmu pengetahuan pada masing-masing mahasiswa, melatih keterampilan yang dimiliki mahasiswa, sehingga dapat bekerja dengan baik, melahirkan sikap bertanggung jawab, disiplin, sikap mental, etika yang baik serta dapat bersosialisasi dengan lingkungan sekitar, menambah kreatifitas mahasiswa, agar dapat mengembangkan bakat yang terdapat dalam dirinya, memberikan motivasi sehingga mahasiswa bersemangat dalam meraih cita-cita mereka, dan melatih mahasiswa, agar dapat membuat suatu laporan yang terperinci dari apa saja yang mereka kerjakan selama Praktik Kerja Industri.

Manfaat Praktik Kerja Industri antara lain menambah wawasan pada mahasiswa, membina hubungan kerja sama yang baik antara pihak kampus dengan perusahaan atau lembaga instansi lainnya, mendapatkan pengalaman untuk bekal pada saat bekerja nantinya, dan menumbuhkan rasa kebersamaan dan kekeluargaan antara pihak kampus dengan pihak perusahaan.

\section{Metode}

Pendekatan yang digunakan oleh penulis pada penelitian ini adalah pendekatan penelitian kualitatif. Menurut Tohirin (dalam Ni Putu Nia Repli Suandewi, 2015), penelitian kualitatif merupakan penelitian yang bermaksud untuk memahami fenomena-fenomena apa yang diphami oleh subyek penelitian misalkan prilaku, persepsi, motivasi, tindakan, dan lainlain secara holistic dan dengan cara deskripsi dalam bentuk kata-kata dan bahasa pada suatu konteks khusus yang alamiah serta dalam memanfaatkan berbagai metode alamiah. Jenis penelitian ini adalah penelitian deskriptif, yaitu penelitian yang berusaha menggambarkan situasi atau kejadian. Data yang dikumpulkan semata-mata bersifat deskriptif, sehingga tidak bermaksud mencari penjelasan, menguji hipotesis, membuat prediksi, maupun mempelajari implikasi. Tujuannya adalah untuk membuat deskripsi, gambaran atau lukisan secara sistematis faktual dan akurat tentang fakta-fakta serta hubungan antara fenomena yang diselidiki.

Pelaksanaan penelitian kualitaif ini bertempat di Prodi S1 Pendidikan Teknik Elektro, Universitaas Pendidikan Ganesha dan juga di perusahaan tempat mahasiswa praktik kerja lapangan. Pemilihan Prodi S1 Pendidikan Teknik Elektro, Universitaas Pendidikan Ganesha sebagai tempat penelitian dikarenakan beberapa pertimbangan, diantaranya 1) Prodi S1 Pendidikan Teknik Elektro, Universitaas Pendidikan Ganesha Singaraja merupakan jurusan yang telah terakreditasi $B$, dengan kinerja jurusan termasuk dosen dan mahasiswa pasti baik, sehingga akan memudahkan proses pengumpulan data; dan 2) lokasi Prodi S1 Pendidikan Teknik Elektro, Universitaas Pendidikan Ganesha berada di daerah perkotaan yang tidak jauh dari tempat tinggal peneliti, sehingga efisiensi baik tenaga, biaya, dan waktu penelitian bisa diperoleh. Berdasarkan hal tersebut, maka Prodi S1 Pendidikan Teknik Elektro, Universitas Pendidikan Ganesha merupakan tempat penelitian yang relevan atau memenuhi syarat bagi penelitian ini.

Data dalam penelitian ini berupa data mentah yang didapatkan peneliti selama di lapangan, yakni fakta-fakta yang belum direduksi mengenai fenomena yang diamati di lapangan. Fakta yang dikumpulkan di lapangan menjadi data yang akan dianalisis. Teknik dalam pengambilan data menggunakan teknik purposive sampling, menurut Sugiyono (2015) teknik purposive sampling adalah teknik pengambilan sampel sumber data dengan 
pertimbangan tertentu, yakni sumber data dianggap paling tahu tentang apa yang diharapkan, sehingga mempermudah peneliti menjelajahi obyek atau situasi sosial yang sedang diteliti.

Sumber data dalam penelitian ini disebut dengan informan, yakni dosen, pihak perusahaan dan mahasiswa yang telah dipilih sesuai dengan pertimbangan dan kesesuaian dengan cakupan tujuan penelitian. Peneliti melakukan pemilihan sumber data berdasarkan variabel-variabel yang akan diungkap di lapangan, seperti 1) letak perusahaan yang dekat; 2) pemilihan mahasiswa pada masing-masing konsentrasi yang ada di Prodi S1 Pendidikan Teknik Elektro; 3) pemilihan dosen berdasarkan keterkaitannya dengan pelaksanaan praktik kerja lapangan; 4) pemilihan perusahaan berdasarkan perusahaan tempat mahasiswa yang dijadikan informan.

Dosen, perusahaan dan mahasiswa yang dijadikan sumber data penelitian adalah Dosen dan Mahasiswa Prodi S1 Pendidikan Teknik Elektro, Universitas Pendidikan Ganesha Singaraja, sedangkan perusahaan adalah instansi pemerintah dan instansi swasta dimana mahasiswa melakukan PKL. Sumber data lainnya berupa dokumentasi, foto, dan dokumen terkait.

Menurut pendapat Sugiyono (2015), terdapat tiga macam teknik pengumpulan data, yaitu observasi, wawancara, dan dokumentasi/studi dokumen, antara lain Observasi, adalah kegiatan keseharian yang dilakukan oleh peneliti dengan menggunakan panca indra sebagai alat bantu untuk melaksanakan pengamatan. Metode observasi yang digunakan dalam penelitian ini adalah observasi partisipasi pasif. Partisipasi pasif adalah teknik observasi dimana peneliti datang ke tempat kegiatan orang yang diamati, tetapi tidak ikut terlibat dalam kegiatan tersebut (Sugiyono, 2008), Wawancara, adalah sebuah dialog yang dilakukan oleh pewawancara untuk memperoleh informasi dari subyek. Teknik wawancara yang digunakan dalam penelitian ini adalah teknik wawancara semi terstruktur. Peneliti menyiapkan instrumen penelitian berupa pertanyaan-pertanyaan tertulis, namun dalam pelaksanaannya konteks wawancara dapat berkembang diluar rubrik wawancara, dan Dokumentasi atau Studi Dokumen, merupakan catatan peristiwa yang sudah berlalu. Dokumen bisa berbentuk tulisan, gambar, atau karya-karya monumental dari seseorang (Sugiyono, 2014). Teknik dokumentasi diperlukan untuk memperkuat bukti dari hasil penelitian. Selain itu, dokumentasi juga digunakan untuk mengecek kembali bila ada data yang belum tercatat maupun bila ada data yang meragukan pada saat observasi dilaksanakan. Teknik dokumentasi dalam penelitian ini dilakukan dengan mengumpulkan dokumen-dokumen terkait, surat pelaksannan PKL, Laporan PKL, hasil ujian PKL untuk selanjutnya dianalisis hubungannya dengan fokus penelitian.

Analisis data yang dilakukan dalam penelitian kualitatif ini berlangsung sejak pengumpulan data di lapangan dan terus-menerus (Suharsaputra, 2012). Analisis data dilakukan sepanjang penelitian berlangsung dan dilakukan secara kontinu, data akan dikumpulkan terlebih dahulu, setelah data dikumpulkan data akan direduksi, setelah itu data akan dipaparkan, setelah direduksi data akan disimpulkan dan verifikasi data. Setiap tahapan analisis data dilakukan pula 3 hal, yakni: 1) data reduction (reduksi data), 2) data display (paparan data), dan 3) conclusion drawing and verification (penarikan simpulan dan verifikasi data). Secara lebih rinci dijelaskan melalui diagram berikut.

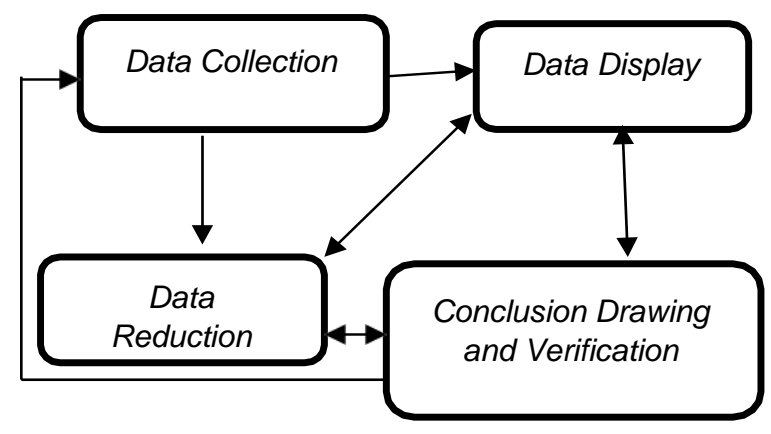

Gambar 1. Analisis Komponen dalam Data (Interactive Model) (Sugiyono, 2008) 
Terdapat dua hal yang perlu dikaji berkaitan dengan keabsahan data, yaitu jumlah data dan kualitas data yang dikumpulkan. Sesuai dengan masalah penelitian dan metode pengumpulan data, data yang dikumpulkan terdiri atas: 1) data hasil observasi lapangan yang dilengkapi dengan rekaman dari proses pelaksanaan PKL di lapangan; 2) data hasil wawancara dengan dosen, pihak perusahaan dan mahasiswa; dan 3) data hasil analisis dokumen pelaksanaan PKL. Selanjutnya data yang sudah terkumpul perlu dikaji kualitasnya, agar hasil pengolahannya dapat mencapai tingkat kepercayaan (credibility) yang setinggitingginya.

Kualitas data yang dikumpulkan harus teruji dari segi reabilitas dan validitasnya. Reabilitas data penelitian ini dapat dipertanggungjawabkan berdasarkan hasil observasi, wawancara, dan studi dokumen yang diperoleh selama penelitian di lapangan dengan sumber data, baik itu dosen, perusahaan dan mahasiswa. Dari segi validitas, informasi yang diperlukan dalam penelitian ini secara nyata. Kebenaran informasi tersebut dapat diketahui berdasarkan: 1) hasil observasi di lapangan, yaitu berupa catatan lapangan yang dibuat oleh peneliti selama observasi; 2) hasil wawancara dengan sumber data penelitian dosen, perusahaan dan mahasiswa berupa rekaman transkrip wawancara selama di lapangan; dan 3) dokumen pelaksanaan PKL yang dianalisis secara nyata.

\section{Hasil dan Pembahasan}

Berdasarkan analisis data, perencanaan administrasi pelaksanaan praktik kerja lapangan yang harus dilengkapi oleh mahasiswa sebelum melaksanakan praktik kerja lapangan terdiri dari memprogram mata kuliah praktik kerja lapangan di semester yang sama, mencari tempat praktik kerja lapangan, formulir data praktik kerja lapangan. Mahasiswa memprogram mata kuliah praktik kerja lapangan di semester yang sama sesuai dengan pedoman dan kebijakan pelaksanaan praktik kerja lapangan LP3M Undiksha yang menyatakan bahwa praktik kerja lapangan diprogram dalam kartu rencana studi (KRS). Mahasiswa memilih dan mencari sendiri perusahaan tempat melaksanakan praktik kerja lapangan yang bekerja di bidang yang sama dengan bidang keahlian mahasiswa terebut dan mahasiswa mendapatkan rekomendasi telah diterima di perusahaan tersebut sesuai dengan pedoman perencanaan pelaksanaan praktik kerja lapangan prodi S1 Pendidikan Teknik Elektro yang menyatakan bahwa mahasiswa harus memiliki surat rekomendasi telah diterima oleh instansi tempat praktik kerja lapangan.

Berdasarkan telaah pedoman pelaksanaan praktik kerja lapangan prodi S1 Pendidikan Teknik Elektro Kurikulum KKNI dapat dipaparkan bahwa secara garis besar susunan rencana pelaksanaan praktik kerja lapangan telah memuat beberapa tahapan sebagai berikut: 1) Mahasiswa memprogram mata kuliah praktik kerja lapangan di semester yang sama, yaitu semester 7 di kartu rencana studi (KRS); 2) Mahasiswa harus mengikuti Unit Bisnis Teknik Elektro selama 3 bulan dan memiliki sertifikat lulus magang dari Unit Bisnis Teknik Elektro; 3) Mahasiswa mencari perusahaan tempat praktik kerja lapangan dan memiliki surat rekomendasi telah diterima oleh instansi tempat praktik kerja lapangan; 4) Mahasiswa mengisi formulir data praktik kerja lapangan; 5) Pembekalan hal ini sesuai dengan pedoman dan kebijakan pelaksanaan praktik kerja lapangan yang dikeluarkan oleh instansi LP3M dan jurusan Teknik Elektro adalah sebagai berikut: 1) Mahasiswa memprogram mata kuliah praktik kerja lapangan di kartu rencana studi (KRS); 2) Mahasiswa harus mengikuti Unit Bisnis Teknik Elektro selama 3 bulan dan memiliki sertifikat lulus magang dari Unit Bisnis Teknik

Elektro; 3) Mahasiswa mencari perusahaan tempat praktik kerja lapangan dan memiliki surat rekomendasi telah diterima oleh instansi tempat praktik kerja lapangan; 4) Mahasiswa mengisi formulir data praktik kerja; dan 5) Pembekalan sebelum mahasiswa terjun ke perusahaan untuk melaksanakan praktik kerja lapangan yang diberikan oleh LP3M dan Jurusan Teknik Elektro.

Manfaat yang dirasakan oleh mahasiswa, pihak prodi S1 Pendidikan Teknik Elektro maupun pihak perusahaan, yaitu 1) Manfaat yang dirasakan oleh mahasiswa adalah sebagai berikut: a) mahasiswa mendapatkan pengalaman dalam menerapkan ilmu yang dimilikinya; 
b) mahasiswa banyak mendapatkan ilmu baru di lapangan; c) mahasiswa mendapatkan jam praktik yang lebih banyak.; 2) Manfaat yang dirasakan oleh prodi S1 Pendidikan Teknik Elektro adalah sebagai berikut: a) Banyaknya pengalaman yang didapat oleh mahasiswa; b) Adanya semacam ikatan antara jurusan dengan perusahaan tempat mahasiswa melakukan praktik kerja lapangan.; 3) Manfaat yang didapat oleh perusahaan atau instansi tempat mahasiswa melakukan praktik kerja lapangan adalah sebagai berikut: a) Mahasiswa dapat membantu pekerjaan di perusahaan atau instansi terkait; b) Pihak perusahaan dan mahasiswa dapat sharing ilmu dan teori yang dimiliki oleh mahasiswa hal ini sesuai dengan pedoman dan kebijakan pelaksanaan praktik kerja lapangan LP3M Undiksha adalah sebagai berikut: 1) Manfaat untuk mahasiswa adalah sebagai berikut: a) Memperluas pengetahuan dan keterampilan dalam bidang keilmuan yang ditekuni; b) Meningkatkan daya kritis serta kepekaannya terhadap masalah-masalah yang ada di tempat pelaksanaan PKL; c) Meningkatkan sikap dan keterampilan dalam memecahkan masalah yang dihadapi; d) Memberikan pengalaman belajar yang mendukung kesiapannya dalam memasuki pasar kerja.; 2) Manfaat untuk jurusan atau prodi S1 Pendidikan Teknik Elektro adalah sebagai berikut: a) Memperoleh umpan balik baagi pengembangan kurikulum, materi perkuliahan,dan metoda yang terkait dengan bidang ilmu yang dikembangkan; b) Perluasaan sosialisasi keberadaan Undiksha yang terkait dengan kelembagaan, bidang keilmuan yang dikembangkan,dan sumber daya manusia yang dimiliki; c) Meningkatkan, memperluas dan memepererat kerjasama dengan instansi pemerintah/swasta melalui rintisaan mahasiswa PKL.; 3) Manfaat untuk Perusahaan adalah sebagai berikut: a) Memperoleh bantuan tenga dan pemikiran dalam penerapan IPTEK; b) Memperoleh bantuan dalam mengembakan berbagai program; c) Memperoleh bantuan dalam memecahkan berbagaio permasalahan yang diadapi oleh mitra.

Perencanaan praktik kerja lapangan yang dilakukan oleh mahasiswa dan jurusan masih memiliki kekurangan diantaranya, seperti 1) Tidak adanya klasisfikasi atau kriteria yang pasti mengenai perusahaan atau instansi tempat mahasiswa melakukan praktik kerja lapangan yang bertujuan agar mahasiswa tidak mencari perusahaan tempat praktik kerja lapangan yang melenceng dari bidang studinya; 2) tidak terlaksananya keseluruhan tahapan yang telah ditetapkan dalam perencanaan praktik kerja lapangan, yaitu mahasiswa diberi kebijakan untuk tidak melakukan magang di Unit Bisnis Teknik Elektro terlebih dahulu dan mahasiswa diberikan kebijakan tidak menyertakan sertifikat lulus magang di Unit Bisnin Teknik Elektro hal ini kurang sesuai dengan pedoman perencanaan pelaaksanaan praktik kerja lapangan prodi S1 Pendidikan Teknik Elektro, dimana tidak semua acuan dari perencanaan praktik kerja lapangan tersebut dipenuhi oleh mahasiswa, sehingga dalam pelaksanaannya mengalami ketidak efisiensi dan perlu adanya pedoman yang jelas terkait perencanaan praktik kerja lapangan prodi S1 Pendidikan Teknik Elektro agar kedepannya menjadi lebih baik lagi.

Pada pelaksanaan praktik kerja lapangan di perusahaan banyak mahasiswa yang mengalami kendala dalam pekerjaanya, maka dari itu peranan pembimbing lapangan dan dosen pembimbing sangat penting untuk membantu mahasiswa mengatasi masalah yang mahasiswa hadapi hal ini sesuai dengan tugas pembimbing praktik kerja lapangan pada pedoman dan kebijakan praktik kerja lapangan LP3M Undiksha adalah sebagai berikut: 1) Berpartisipasi dalam pembekalan; 2) Mendampingi dalam penyerahan mahasiswa ke lokasi PKL; 3) Mendampingi mahasiswa dalam penyusunaan program PKL; 4) Memberikan bimbingan secara rutin sesuai dengan waktu yang telah ditentukan; 5) Membimbing mahasiswa dalam pembuatan laporan kegiatan PKL; 6) Mendampingi mahasiwa dalam kegiatan perpisahan; 7) Memeriksa absensi mahasiswa; 8) Mengecek kegiatan mahasiswa pada buku kegiatan harian; dan 9) Menginformasikan berbagai kebijakan dari panitia PKL Memberikan bimbingan dalam memecahakan permasalahan dan hambatan yang dihadapi.

Mahasiswa dalam kegiatan sehari-hari harus mencatat kegiatan atau pekerjaan yang dilakukan, agar dosen dan pihak jurusan mengetahui bagaimana kegiatan mahasiswa tersebut dimana format penulisan aktivitas sehari-hari mahasiswa dapat dilihat di pedoman praktik kerja lapangan prodi S1 Pendidikan Teknik Elektro, seperti nomor, hari/tanggal, aktivitas dan paraf pembimbing. Kegiatan terakhir dalam pelaksanaan praktik kerja lapangan 
adalah menyusun laporan akhir praktik kerja lapangan dimana hal ini sesuai dengan ketentuan yang ada dalam pedoman dan format penulisan laporan akhir praktik kerja lapangan. Pelaksanaan praktik kerja lapangan mahasiswa prodi S1 Pendidikan Teknik Elektro sudah sangat efektif dalam meningkatkan kemampuan dan keahlian mahasiswa.

Pihak prodi S1 Pendidikan Teknik elektro sudah berusaha menerapkan penilaian atau evaluasi yang sesuai dengan pedoman praktik kerja lapangan prodi S1 Pendidikan Teknik Elektro, dimana penilaian ini ada 2, yaitu penilaian dari kegiatan mahasiswa di lapangan dan ujian akhir praktik kerja lapangan. Penilaian praktik kerja lapangan mengacu pada beberapa aspek penilaian, yaitu 1) Deliverables; 2) Ketepatan waktu; 3) Kehadiran; 4) Attitude;5) Team work; dan 6) inisiatif. 1) Deliverables merupakan point penilaian mengenai hasil akhir dari pelaksanaan praktik kerja lapangan dengan bobot penilaian $10 \%$; 2) Ketepatan waktu merupakan point penilaian mengenai pelaksanaan pekerjaan yang diberikan sesuai dengan batas waktu yang telah diberikan dengan bobot penilaian $10 \%$; 3) Kehadiran merupakan tingkat kehadiran mahasiswa sesuai dengan kondisi atau requirement yang diberikan oleh perusahaan pada awal kegiatan prktik kerja lapangan, termasuk ketepatan masuk atau keluar kantor dengan bobot penilaian 20\%; 4) Attitude meliputi sikap dan kerapihan mahasiswa di tempat praktik kerja lapangan dengan bobot penilaian 10\%; 5) Team work merupakan kerjasama antara mahasiswa dengan personil lain di perusahaan atau instansi yang bersangkutan, termasuk kemmpuan berkomunikasi dengan bobot penilaian $40 \%$; dan 6) inisiatif, pemahaman terhadap materi atau masalah di tempat praktik kerja lapangan dengan bobot penilaian sebanyak $10 \%$, dengan catatan jika mahasiswa mendapatkan nilai dibawah 60 , berarti mahasiswa yang bersangkutan tidak disarankan untuk lulus dari mata kuliah praktik kerja lapangan.

Penilaian pelaksanaan praktik kerja lapangan juga menggunakan ujian akhir yang dilakukan setelah mahasiswa selesai mengikuti kegiatan praktik kerja lapangan, syarat mengikuti ujian akhir ini adalah mahasiswa harus mengumpulkan laporan akhir praktik kerja lapangan yang sudah disetujui oleh dosen pembimbing dan pembimbing lapangan di perusahaan tempat mahasiswa melakukan praktik kerja lapangan tersebut.

Dari evaluasi tersebut dapat dilihat bahwa hasil pelaksanaan praktik kerja lapangan sangat bagus dan efektif bagi mahasiswa. Terbukti dari mahasiswa yang melakukan praktik kerja lapangan sudah memenuhi semua variabel penilaian praktik kerja lapangan sudah memenuhi $100 \%$ dari tingkat kelulusan mahasiswa yang mengikuti praktik kerja lapangan yang mencapai 97\%, dimana hanya 1 mahasiswa yang tidak lulus dari keseluruhan mahasiswa yang mengikuti praktik kerja lapangan tahun 2017 sebanyak 30 orang. Jadi pelaksanaan praktik kerja lapangan mahasiswa prodi S1 Pendidikan Teknik Elektro sudah memenuhi $97 \%$ dari pelaksanaan praktik kerja lapangan yang efektif.

\section{Kesimpulan dan Saran}

Berdasarkan hasil penelitian dan pembahasan dapat disimpulkan sebagai berikut: 1) Perencanaan dan persiapan pelaksanaan praktik kerja lapangan prodi S1 Pendidikan Teknik Elektro masih memiliki kekurangan, yaitu tidak adanya kriteria perusahaan tempat mahasiswa melakukan praktik kerja lapangan yang jelas; 2) Pelaksanaan praktik kerja lapangan mahasiswa prodi S1 Pendidikan Teknik Elektro. Pelaksanaan praktik kerja lapangan sudah efektif terbukti dengan tingkat kelulusan mahasiswa yang mengikuti praktik kerja lapangan yang mencapai $97 \%$, dimana tingkat ketidak lulus sebesar $3 \%$ dari keseluruhan mahasiswa yang mengikuti praktik kerja lapangan tahun 2017 sebanyak 30 orang; dan 3) Evaluasi dan penilaian praktik kerja lapangan mahasiswa prodi S1 Pendidikan Teknik Elektro ada penilaian kegiatan sehari-hari mahasiswa dan penilaian dari hasil ujian akhir praktik kerja lapangan.

Secara empirik penelitian ini telah mampu mengungkap efektifitas pelaksanaan praktik kerja lapangan mahasiswa prodi S1 Pendidikan Teknik Elektro Undiksha dalam meningkatkan kemampuan dan keahlian mahasiswa.

Sesuai dengan temuan dalam penelitian ini, saran yang dapat disampaikan sebagai berikut: 1) Pihak prodi S1 Pendidikan Teknik Elektro lebih memperhatikan tentang kriteria perusahaan yang dapat dijadikan tempat praktik kerja lapangan oleh mahasiswa, agar 
mahasiswa tidak salah dalam memilih tempat praktik kerja lapangan, selain itu pihak prodi S1 Pendidikan Teknik elektro diharapkan mempunyai pedoman praktik kerja lapangan yang jelas agar tidak terjadi penyimpangan dalam pelaksanaannya; 2) Dalam pembekalan pelaksanaan praktik kerja lapangan diharapkan pihak jurusan menekankan pentingnya sikap disiplin saat bekerja di perusahaan dan juga meningkatkan mental mahasiswa sebelum terjun ke lapangan; dan 3) Mahasiswa diharapkan dalam melakukan praktik kerja lapangan secara sunguh-sungguh dan juga mahasiswa harus memperhatikan etika berpakaian saat bekerja dan selalu menggunakan alat keselamatan saat bekerja.

\section{Daftar Pustaka}

Arikunto, Suharsimin, dan Cepi Safrudin Abdulah Jabar. 2009. "Evaluasi Program Pendidikan". Jakarta: Bumiaksara.

Kementerian Pendidikan dan Kebudayaan. 2003. Undang-Undang nomor 20 tahun 2003. tentang Sistem Pendidikan Nasional.

Mestia Wendy Gustiariningsih, Ni Nyoman. 2015. "Evaluasi Pelaksanaan Sistem Informasi Kuliah Kerja Nyata (KKN) Menggunakan Metode CIPP (Context, Input, Process, Product) Study Kasus: Universitas Pendidikan Ganesha”. Skripsi [Tidak diterbitkan]. Universitas Pendidikan Ganesha.

Jurusan Teknik Elektro. 2016. "Katalog Prodi S1 Pendidikan Teknik Elektro Kurikulum KKNI". Singaraja. Prodi S1 Pendidikan Teknik Elektro

Sugiyono. 2015. "Metode penelitian pendidikan: Pendekatan kuantitatif, kualitatif, dan R\&D". Bandung: Alfabeta.

Suharsaputra, U. 2012. "Metode penelitian kuantitatif, kualitatif, dan tindakan”. Bandung: Refika Aditama.

Universitas Pendidikan Ganesha. 2012. Surat Keputusan Rektor Undiksha Nomor 610/UN.48/PP/2012 tentang Pedoman Studi. 